\title{
Impairment of gas exchange and structure in birch leaves (Betula pendula) caused by low ozone concentrations
}

\author{
Rainer Matyssek, Madeleine S. Günthardt-Goerg, Theodor Keller, and Christoph Scheidegger \\ Swiss Federal Institute of Forest, Snow and Landscape Research, Zürcherstraße 111, CH-8903 Birmensdorf ZH, Switzerland
}

Received October 11, 1990/November 19, 1990

Summary. Injury caused by low $\mathrm{O}_{3}$ concentrations $\left(0,0.05,0.075,0.1 \mu 11^{-1}\right)$ was analyzed in the epidermis and mesophyll of fully developed birch leaves by gas exchange experiments and low-temperature SEM: (I) after leaf formation in $\mathrm{O}_{3}$-free and ozonated air, and (II) after transferring control plants into ozonated air. In control leaves, autumnal senescence also was studied in $\mathrm{O}_{3}$-free air (III). As $\mathrm{O}_{3}$ concentration increased, leaves of (I) stayed reduced in size, but showed increased specific weight and stomatal density. The declining photosynthetic capacity, quantum yield and carboxylation efficiency lowered the light saturation of $\mathrm{CO}_{2}$ uptake and the water-use efficiency (WUE). Carbon gain was less limited by the reduced stomatal conductance than by the declining ability of $\mathrm{CO}_{2}$ fixation in the mesophyll. The changes in gas exchange were related to the $\mathrm{O}_{3}$ dose and were mediated by narrowed stomatal pores (overriding the increase in stomatal density) and by progressive collapse of mesophyll cells. The air space in the mesophyll increased, preceded by exudate formation on cell walls. Ozonated leaves, which had developed in $\mathrm{O}_{3}$-free air (II), displayed a similar but more rapid decline than the leaves from (I). In senescent leaves (III), $\mathrm{CO}_{2}$ uptake showed a similar decrease as in leaves with $\mathrm{O}_{3}$ injury but no changes in mesophyll structure and WUE. The nitrogen concentration declined only in senescent leaves in parallel with the rate of $\mathrm{CO}_{2}$ uptake. A thorough understanding of $\mathrm{O}_{3}$ injury and natural senescence requires combined structural and functional analyses of leaves.

Key words: Ozone - Betula pendula - Leaf gas exchange - Leaf structure - Senescence

\section{Introduction}

In recent studies on forest decline in Europe, the direct impact of air pollutants on conifer foliage was not found to

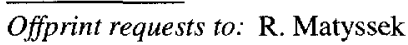

be the primary cause of reduced tree vigor (Koch and Lautenschlager 1988; Schulze 1989). Xerophytic conifer needles, which are characterized by low photosynthetic capacity and low stomatal conductance (Körner et al. 1979), may indeed be less prone to pollutant uptake and injury than leaves with high capacity and conductance (Reich 1987). Plants with these latter features, such as agricultural crops and broad-leaved trees, are known to be impaired by the low ozone concentrations nowadays prevailing in many natural environments (Reich and Amundsen 1985). However, most findings on broad-leaved trees derive from species native to North America, while much less is known about the response of European tree species to low ambient ozone levels. The fact that in rural sites of Central Europe the $\mathrm{CO}_{2}$ assimilation of herbaceous crops is limited by ozone (Lehnherr et al. 1987) must direct attention to the ozone sensitivity of European trees with mesophytic leaves.

In contrast to the knowledge about the impact of $\mathrm{SO}_{2}$ in leaves, few mechanistic studies have been carried out about developing ozone injury in the leaf epidermis and mesophyll (Mohren 1988; Mooney and Winner 1988). Moreover, some former investigations may reflect artifacts related to the way the ozone was generated (Brown and Roberts 1988).

Therefore, this study on cuttings of the mesophytic European tree species Betula pendula addressed processes of onsetting leaf injury with analytical gas exchange experiments (Lange et al. 1987) and 'low-temperature scanning electron microscopy' (Beckett and Read 1986; Scheidegger et al. 1991), using low ozone concentrations generated from pure oxygen. The approach also compared the decline of ozonated leaves with that of autumnal leaf senescence.

\section{Materials and methods}

Plants and ozone fumigations. From 14 April through 1 November 1989 cuttings of one birch clone (Betula pendula Roth) were grown in 101 pots filled with sand and a basal layer of inert synthetic clay beads ( 1 plant/pot, fertilized, well-watered). When transferred into the field 
Table 1. Ozone concentrations and doses of the fumigation experiments and in the ambient air at the experimental site (in the rural surroundings of Zurich, Switzerland) from mid-May through early October 1989

Fumigation treatments:

Ozone concentrations

continuously applied

$\left(\mu 11^{-1}\right)$ :

$\begin{array}{lll}0 & 0.050 \quad 0.075\end{array}$

0.100

(control)

Ambient air at the

experimental site:

Number of hours with

higher ozone concentrations

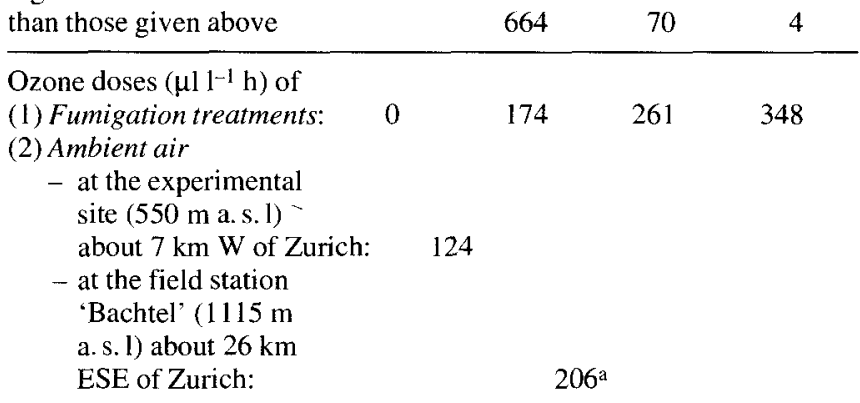

a Measured by ATAL/Zurich (Mr. Waldenmeyer)

fumigation chambers (Keller 1976) on 16 May 1989, the plants were separated into four $\mathrm{O}_{3}$ treatments $(20$ plants/treatment, 4 plants/chamber). The $\mathrm{O}_{3}$ concentrations were 0 (control), $0.05,0.075$, and $0.1 \mu \mathrm{l}^{-1}$, and monitored by a 'Monitor Labs 8810' instrument. Ozone was generated from pure oxygen (Fischer, model 502) and continuously added to charcoal-filtered air. The treatments covered the range of $\mathrm{O}_{3}$ concentrations and doses measured in the region around the experimental site (Table 1).

Leaves selected in investigations. Structure and gas exchange of similarly aged, fully developed leaves attached to the main stem were compared between $\mathrm{O}_{3}$-fumigated and control plants: from June through August with leaves, which had formed during $\mathrm{O}_{3}$ exposure (investigation $\mathrm{I}$ ). The leaves selected were either without visual symptoms or with early visual $\mathrm{O}_{3}$ injury (little, light-green yellowish dots) or with established yellowish-bronze discoloration and the onsetting formation of tiny black necroses. Advanced $\mathrm{O}_{3}$ injury (large necroses, wilting, premature leaf loss) was not investigated. In September, investigation II addressed control plants with leaves, which had almost completed development before being ozonated with $0.1 \mathrm{H} \mathrm{I}^{-1}$ since 21 August 1989. With similar leaf selection, tiny black necroses occurred earlier than in (I) and before the yellowish discoloration. In October (investigation III), senescent but still turgescent control leaves were compared until complete yellowing with mid-summer control leaves and with ozonated leaves.

Gas exchange experiments. These were conducted on attached complete leaves with a thermo-electrically climate-controlled cuvette system (Walz), which was installed in the field close to the fumigation chambers. The evening before the measurement, plants randomly chosen from treatments were brought to the measuring site and were shielded from direct sunlight and rain during the experiments. Transpiration rate was determined using Walz dewpoint mirrors and a by-pass loop. The mass flow of the by-pass through a water trap was controlled by a differential $\mathrm{H}_{2} \mathrm{O}$ IR gas analyzer (BINOS $4 \mathrm{~b}$, Leybold-Heraeus) to zero vapor differences between cuvette inlet and outlet. Differential and absolute $\mathrm{CO}_{2}$ BINOS $4 \mathrm{~b}$ measured the net- $\mathrm{CO}_{2}$ uptake of the leaf and the absolute $\mathrm{CO}_{2}$ concentration, $\mathrm{c}_{\mathrm{a}}$, of the $\mathrm{O}_{3}$-free system air. $\mathrm{C}_{\mathrm{a}}$ was adjusted by a mass flow-controlled $\mathrm{CO}_{2}$-dispensing system (Walz). The intensity, $\mathrm{I}$, of the artificial light source used ( 8 'Multi-Mirror' halogen bulbs, General Electric) was measured with a GaAsP photodiode (Hamamatsu G1118) after calibration with a quantum sensor (LI-190, LICOR), leaf temperature, $T_{1}$, was registered with a $0.1 \mathrm{~mm}$ chromel/alumel thermocouple.

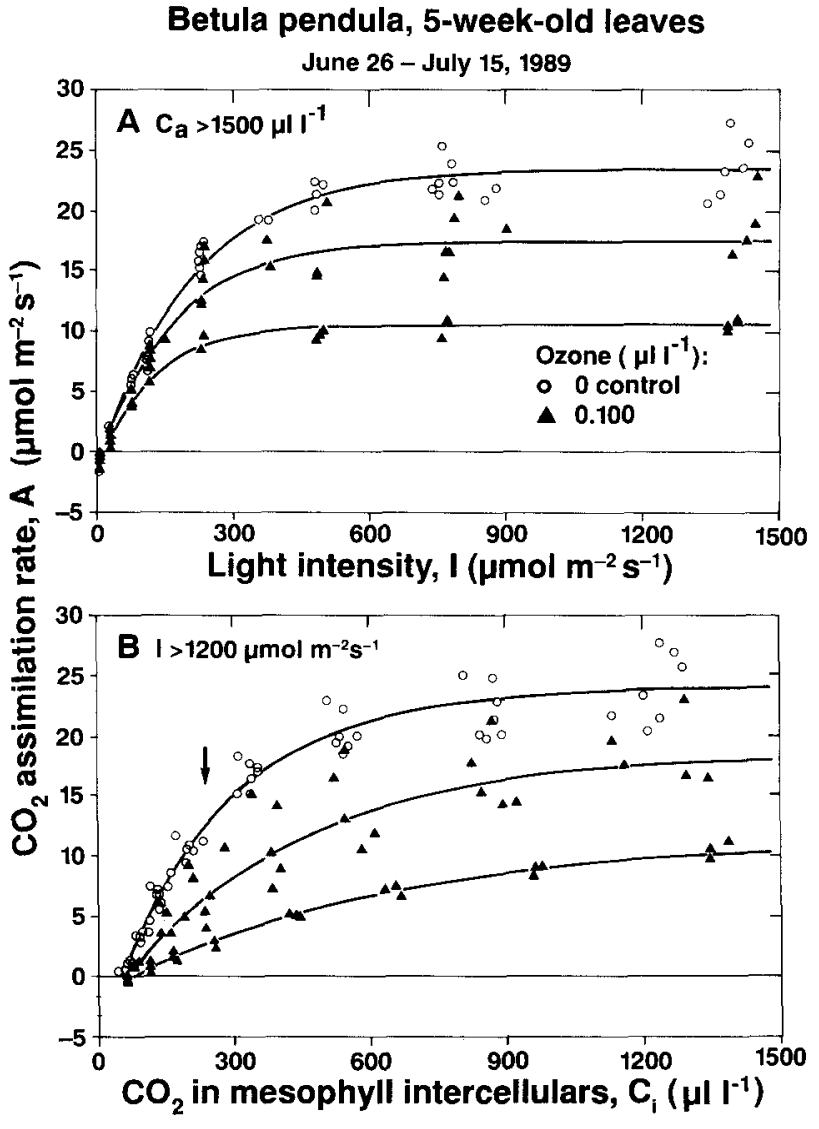

Fig. 1. Investigation $\mathrm{I} ; \mathbf{A}: \mathrm{CO}_{2}$ assimilation rate as dependent on light intensity (experiment 1) and, $\mathbf{B}$ : on the $\mathrm{CO}_{2}$ concentration of the mesophyll intercellulars (experiment 2; the same leaves as in A). The responses of 7 control leaves are compared with those of 8 ozonated leaves, each leaf representing an individual plant; drawn lines represent mean functions of leaves with similar light and $\mathrm{CO}_{2}$ responses: upper line $=$ control and ozonated leaves without visual symptoms, 2nd line from top = early visual ozone symptoms, lowermost line = established $\mathrm{O}_{3}$ discoloration (see Materials and methods). Plateaus give mean photosynthetic capacity, $A_{\max }$

Gas exchange rates were based on the one-sided leaf area (including discolored leaf parts), which was determined with the Delta-T areameter MK2. The nitrogen concentration, $\mathrm{N}$, of experimental leaves was assessed with a Carlo Erba NA1500 analyzer.

Controlling $\mathrm{I}, \mathrm{T}_{\mathrm{l}}, \Delta \mathrm{w}$ (leaf/air mole fraction difference of water vapor), and $\mathrm{c}_{\mathrm{a}}$, each leaf selected in investigations (I), (II), and (III) was analyzed by four experiments. In experiment 1 the light response of gas exchange $\left(\mathrm{c}_{\mathrm{a}}>1500 \mathrm{\mu l} \mathrm{l}^{-1}\right.$ to minimize stomatal limitation of $\mathrm{CO}_{2}$ uptake; Lange et al. 1987); in experiment 2 the $\mathrm{CO}_{2}$ response ( $\mathrm{I}>1200 \mu \mathrm{mol}$ photons $\mathrm{m}^{-2} \mathrm{~s}^{-1}$ ); in experiment 3 the leaf response to constant cuvette conditions during $90 \mathrm{~min}\left(\mathrm{I}>1200 \mu \mathrm{mol}\right.$ photons $\mathrm{m}^{-2} \mathrm{~s}^{-1}$ and $\mathrm{c}_{\mathrm{a}}=$ $340 \mu \mathrm{l}^{-1}$ ); and in experiment 4 the dark respiration rate (cuvette tightly darkened with aluminum foil) was studied. In all four experiments $T_{1}$ was $20^{\circ} \mathrm{C}$ and $\Delta \mathrm{w}=10 \mathrm{mmol} \mathrm{mol}^{-1}$, while 'steady-state' rates of $\mathrm{CO}_{2}$ uptake and, in experiment 3 , of transpiration were allowed to establish. $\mathrm{CO}_{2}$ uptake rates at $\mathrm{I}>1200 \mu \mathrm{mol}$ photons $\mathrm{m}^{-2} \mathrm{~s}^{-1}$ and $\mathrm{c}_{\mathrm{a}}>1500 \mu \mathrm{l} \mathrm{\textrm {I } ^ { - 1 }}$ are denoted as $A_{\max }$. Investigating one leaf per day, the four experiments were always run in the same order and at the same time (between 7 a.m. -1 p. m.).

Leaf structure. Stomatal apertures and mesophyll structure of 3 leaves per treatment (1 leaf/plant) were investigated in (I), (II) and (III) by low-temperature scanning electron microscopy (SEM) in a Balzers cryopreparation unit SCU 020 (Müller et al. 1991). For this purpose, one leaf disc ( $\varnothing=8 \mathrm{~mm}$ between 2 nd-order veins) from each half of the central 
Betula pendula

June 26 -Aug. 25, 1989

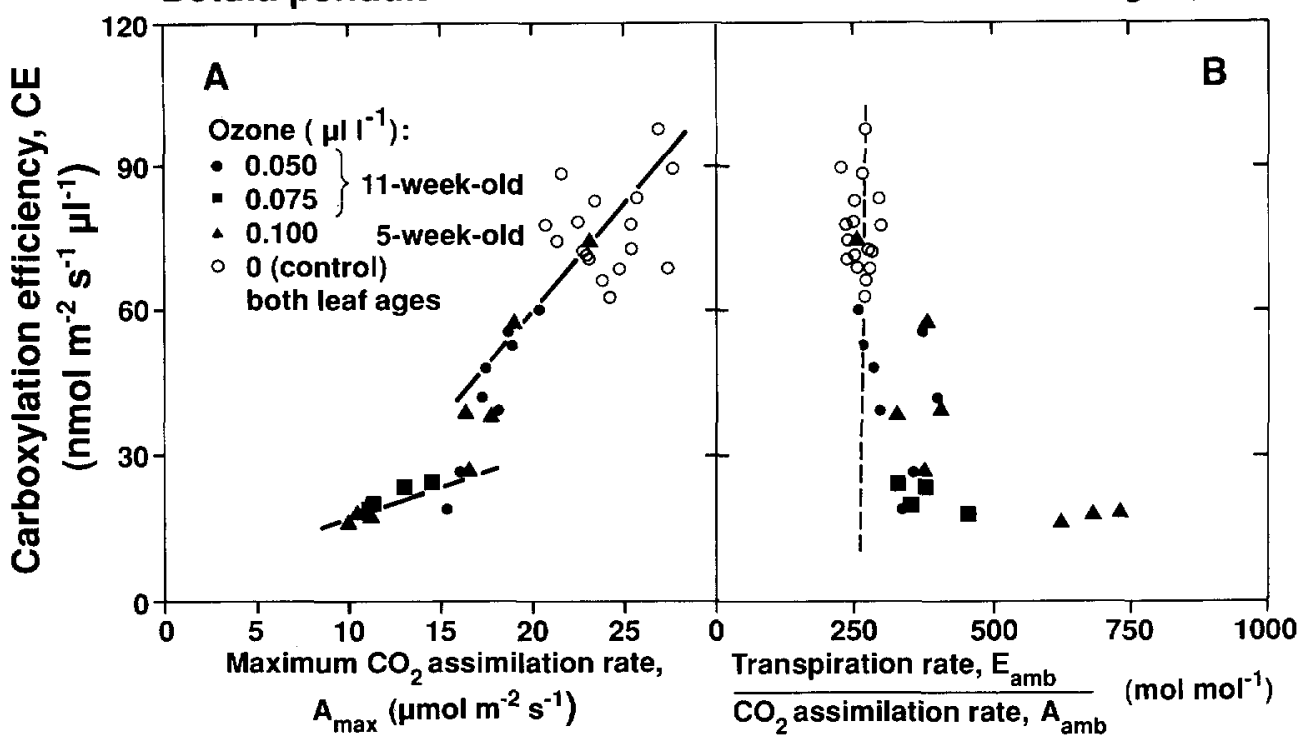

Fig. 2. Investigation I; leaves from all four ozone treatments (including the leaves of Fig. 1; each data point represents one individual leaf and plant). The $\mathrm{O}_{3}$ doses were $84 \mu \mathrm{l} \mathrm{l}^{-1} \mathrm{~h}$ for 5 -week-old leaves at $0.1 \mu \mathrm{l}^{-1}$; $92 \mu \mathrm{l} \mathrm{l}^{-1} \mathrm{~h}$ for 11 -week-old leaves at $0.05 \mu \mathrm{l}^{-1}$; and $139 \mu \mathrm{l}^{-1} \mathrm{~h}$ for 11 -week-old leaves at $0.075 \mu \mathrm{I} \mathrm{I}^{-1}$ (see text). A: carboxylation efficiency $(\mathrm{CE})$ as related to maximum $\mathrm{CO}_{2}$-uptake rate, $\mathrm{A}_{\max }$, of individual leaves

(experiment 2); the upper line includes data from leaves with and without early visual $\mathrm{O}_{3}$ symptoms, the lower line includes leaves with established $\mathrm{O}_{3}$ discoloration. $\mathrm{B}: \mathrm{CE}$ as related to the ratio $\mathrm{E}_{\mathrm{amb}} / \mathrm{A}_{\mathrm{amb}}\left(=\mathrm{WUE}^{-1}\right)$ at $c_{\mathrm{a}}=340 \mu \mathrm{l}^{-1}$ (experiment 3 ); the dashed line gives the mean ratio of the control

lamina had been excised at about 8 a.m. (relative humidity $>70 \%$ at $20^{\circ} \mathrm{C}$ ) into a humid chamber and frozen in liquid nitrogen immediately thereafter. Findings by this sampling procedure were consistent with those of freezing complete leaves before excision from the stem (Scheidegger et al. 1991). The stomatal density was obtained from discs excised into methanol, dyeing guard cells with JJK solution and then

counting stomata under a light microscope at 10 randomly chosen disc positions of $0.3 \mathrm{~mm}^{2}$ area each ( 5 leaves/treatment).

The inner air space (expressed as a percentage of the total leaf volume) of five further leaves per treatment was determined according to Koike (1988). Specific leaf weight (SLW) was calculated as dry weight by one-sided area.

Table 2. Gas exchange characteristics of control, ozonated and senescent birch leaves (absolute maxima and minima of leaves measured)

A: leaves formed under ozone during early summer (I)

\begin{tabular}{|c|c|c|c|c|}
\hline & \multicolumn{4}{|c|}{ Ozone concentration $\left(\mu 11^{-1}\right)$} \\
\hline Leaf age (weeks): & 5 and 11 (pooled) & 11 & 5 & \\
\hline$c_{i}\left(\mu 11^{-1} ;\right.$ at $c_{a}=340 \mu 1 \mathrm{l}^{-1} ;$ Expt. 3): & $242-260$ & $252 \rightarrow 287$ & 244 & $\rightarrow 310$ \\
\hline $\mathrm{CE}\left(\mathrm{nmol} \mathrm{m} \mathrm{m}^{-2} \mathrm{~s}^{-1} \mu \mathrm{l}^{-1} ;\right.$ Expt. 2$)$ & $60-100$ & $\rightarrow 20$ & 75 & $\rightarrow 20$ \\
\hline $\mathrm{CO}_{2}$ compensation point $\left(\mu \mathrm{l} \mathrm{l}^{-1}\right.$; Expt. 2$)$ : & $36-58$ & $\rightarrow 76$ & 51 & $\rightarrow 97$ \\
\hline
\end{tabular}

B: 8-week-old control leaves ozonated in mid-summer (II) and autumnal senescence of control leaves formed in mid-summer (III)

\begin{tabular}{llr} 
Ozone concentration $\left(\mu 1^{-1}\right)$ & & \\
\hline 0 & 0.100 & $0\left(^{*}\right)$ \\
(control, September) & $($ II) & (III) \\
\hline $21.6-25.5$ & $18.5 \rightarrow 5.3$ & $22.1 \rightarrow 7.3$ \\
$229-240$ & $247 \rightarrow 304$ & $228-258$ \\
$60-110$ & $70 \rightarrow 10$ & $80 \rightarrow 20$ \\
$36-58$ & $48 \rightarrow 83$ & $45 \rightarrow 70$ \\
$90-110$ & $90 \rightarrow 30$ & $110 \rightarrow 40$ \\
$7-15$ & $5 \rightarrow 35$ & $12 \rightarrow 30$
\end{tabular}

$A_{\max }\left(\mu \mathrm{mol} \mathrm{m} \mathrm{m}^{-2} \mathrm{~s}^{-1} ;\right.$ Expts. 1 and 2$)$ :

$c_{i}\left(\mu \mathrm{l}^{-1} ;\right.$ at $c_{a}=340 \mu \mathrm{l} \mathrm{l}{ }^{-1} ;$ Expt. 3):

$\mathrm{CE}\left(\mathrm{nmol} \mathrm{m} \mathrm{m}^{-2} \mathrm{~s}^{-1} \mu \mathrm{I}^{-1}\right.$; Expt. 2):

$\mathrm{CO}_{2}$ compensation point $\left(\mu \mathrm{l}^{-1}\right.$; Expt. 2):

QY (nmol $\mu \mathrm{mol}^{-1}$; Expt. 1):

Light compensation point $\left(\mu \mathrm{mol} \mathrm{m}{ }^{-2} \mathrm{~s}^{-1}\right.$; Expt. 1):

\begin{tabular}{r} 
Ozone concentr \\
\cline { 2 - 2 } (control, Septem \\
$21.6-25.5$ \\
$229-240$ \\
$60-110$ \\
$36-58$ \\
$90-110$ \\
$7-15$
\end{tabular}

(*) senescent leaves with $A_{a m b}>1 \mu \mathrm{mol} \mathrm{m}^{-2} \mathrm{~s}^{-1}$ (Exp. 3; Fig. 6); $\rightarrow$ gives tendency of change at beginning leaf injury;

$\mathrm{CE}$ at $\mathrm{c}_{\mathrm{i}}<100 \mu \mathrm{l}^{-1}\left(\mathrm{I}>1200 \mu \mathrm{mol} \mathrm{m} \mathrm{m}^{-2} \mathrm{~s}^{-1}\right.$, same I also for $\mathrm{CO}_{2}$ compensation point $)$;

$\mathrm{QY}$ at $\mathrm{I}<100 \mu \mathrm{mol} \mathrm{m}{ }^{-2} \mathrm{~s}^{-1}\left(\mathrm{c}_{\mathrm{a}}>1500 \mu \mathrm{l} \mathrm{l}^{-1}\right.$, same $\mathrm{c}_{\mathrm{a}}$ also for light compensation point $)$ 


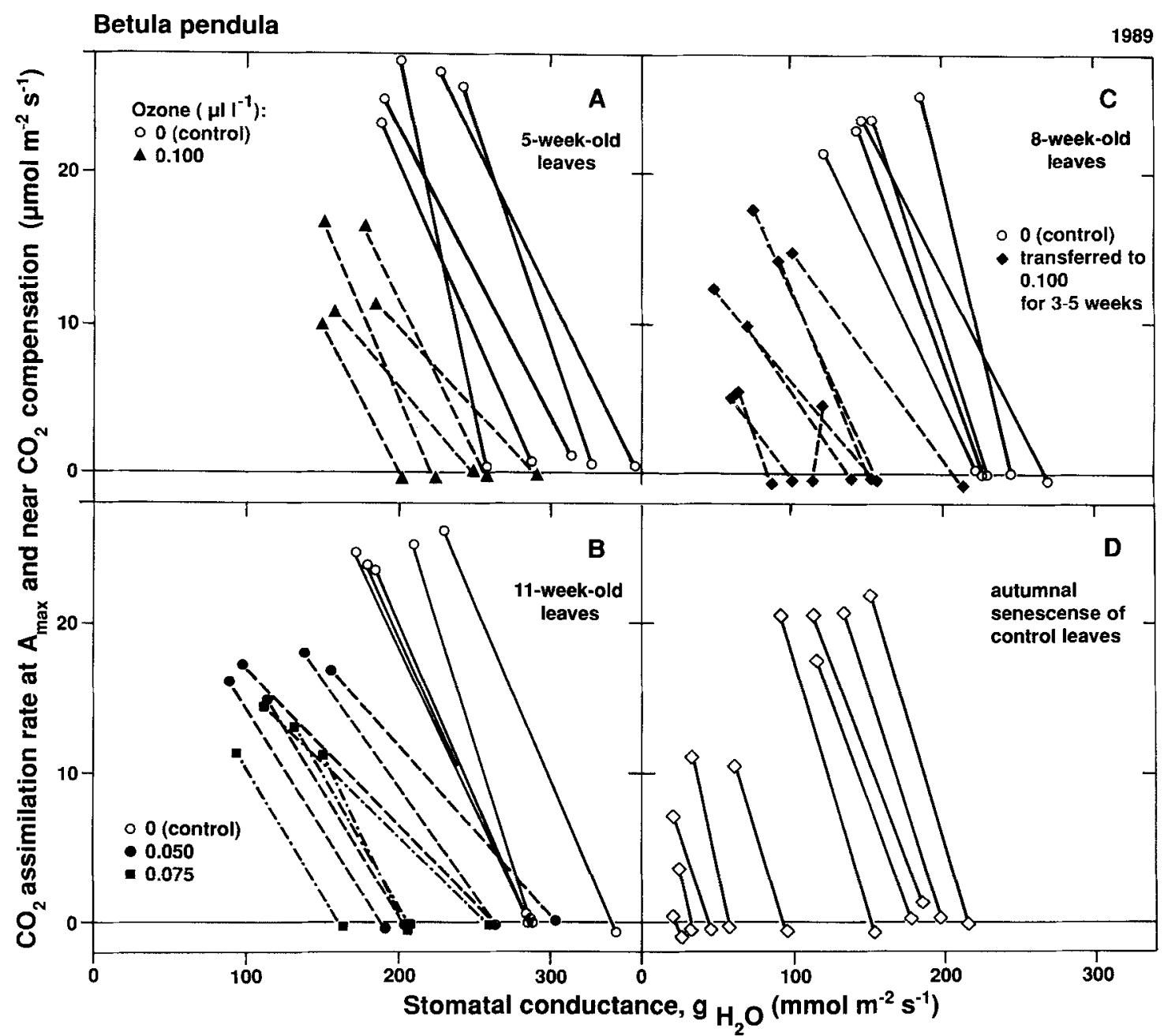

Fig. 3A-D. $A_{\max }\left(a t c_{a}>1500 \mu l^{-1}\right.$ ) and $\mathrm{CO}_{2}$ uptake rate near $\mathrm{CO}_{2}$ compensation point (Table 2) as related to their corresponding stomatal conductances (experiment 2). For clarity, straight lines assign these cardinal points to individual leaves and plants, though in the given range of the driving variable $c_{a}$ (which is not shown in this plot) the $\mathrm{CO}_{2}$ uptake rate non-linearly relates to gH2O. In A and B (both investigation I) only control leaves with 5 highest and ozonated leaves with 5 lowest $A_{\max }$ are shown, in $\mathbf{C}$ (investigation II) and $\mathbf{D}$ (investigation III) all leaves are shown

\section{Results}

The gas exchange of leaves formed under ozone (I)

$\mathrm{O}_{3}$ injury gradually became apparent when the light response of the $\mathrm{CO}_{2}$ assimilation rate, $\mathrm{A}$ (at high $\mathrm{c}_{\mathrm{a}}$ ), of ozonated leaves was compared with that of control leaves (Fig. 1 A). Under $\mathrm{O}_{3}$ stress, $\mathrm{A}_{\max }$ was more strongly depressed than the quantum yield, QY (at low irradiance). Thus, the saturating light intensity of A shifted from about $800 \mu \mathrm{mol}$ photons $\mathrm{m}^{-2} \mathrm{~s}^{-1}$ in the control (and in ozonated leaves without visual symptoms) to $300 \mu \mathrm{mol}$ photons $\mathrm{m}^{-2}$ $\mathrm{s}^{-1}$ in ozonated leaves with established discoloration. However, the $\mathrm{CO}_{2}$ response of light-saturated A (Fig. 1B) showed the $\mathrm{O}_{3}$-induced reduction of $\mathrm{A}_{\max }$ as well as a distinct decrease in the carboxylation efficiency, $\mathrm{CE}$ (at low $\mathrm{CO}_{2}$ concentration). The declining $\mathrm{CE}$ limited the $\mathrm{CO}_{2}$ gain from ambient air of $c_{a}=340 \mu \mathrm{l}^{-1}$ (and thus, from the corresponding $\mathrm{CO}_{2}$ concentrations in the mesophyll intercellulars, $\mathrm{c}_{\mathrm{i}}$; Fig. $1 \mathrm{~B}$, arrow). The lowered ' $\mathrm{CO}_{2}$ affinity' of

ozonated leaves was equally apparent when A was related to $c_{a}$ (not shown; cf. Terashima et al. 1988).

The changes in Fig. 1 reflect a dose effect of ozone on gas exchange. Five-week-old leaves under the $0.1 \mu \mathrm{l} \mathrm{1}^{-1}$ $\mathrm{O}_{3}$ treatment had received about the same $\mathrm{O}_{3}$ dose as 11 -week-old leaves at $0.05 \mu \mathrm{ll}^{-1}$ (i.e. $84-92 \mu \mathrm{l} \mathrm{l}-1 \mathrm{~h}$ ), while the relationship between $\mathrm{CE}$ and $\mathrm{A}_{\max }$ followed a similar decline pattern under these two $\mathrm{O}_{3}$ fumigations (Fig. 2 A). All 11-week-old leaves measured at $0.075 \mu 1 \mathrm{l}^{-1}$ $\left(\mathrm{O}_{3}\right.$ dose $\left.=139 \mu \mathrm{l} \mathrm{l}^{-1} \mathrm{~h}\right)$ displayed advanced decline. Though leaf injury progressed individually, $A_{\max }, C E$ and QY were decreased (Table 2A), but $c_{i}$ and the $\mathrm{CO}_{2}$ compensation point were increased to similar extents at each $\mathrm{O}_{3}$ fumigation (no clear change in light compensation at high $c_{a}$; Table $2 \mathrm{~A}$ ).

Stomata maintained their sensitivity to $\mathrm{CO}_{2}$ under $\mathrm{O}_{3}$ stress, as the stomatal conductance, $\mathrm{g}_{2} \mathrm{O}$, was higher near the $\mathrm{CO}_{2}$ compensation point than at $\mathrm{A}_{\max }$ (Fig. 3A, B). Nevertheless, the $\mathrm{O}_{3}$-induced decline of $\mathrm{CE}$ (Fig. $2 \mathrm{~A}$ ) was coupled with the progressively increasing ratio of tran- 


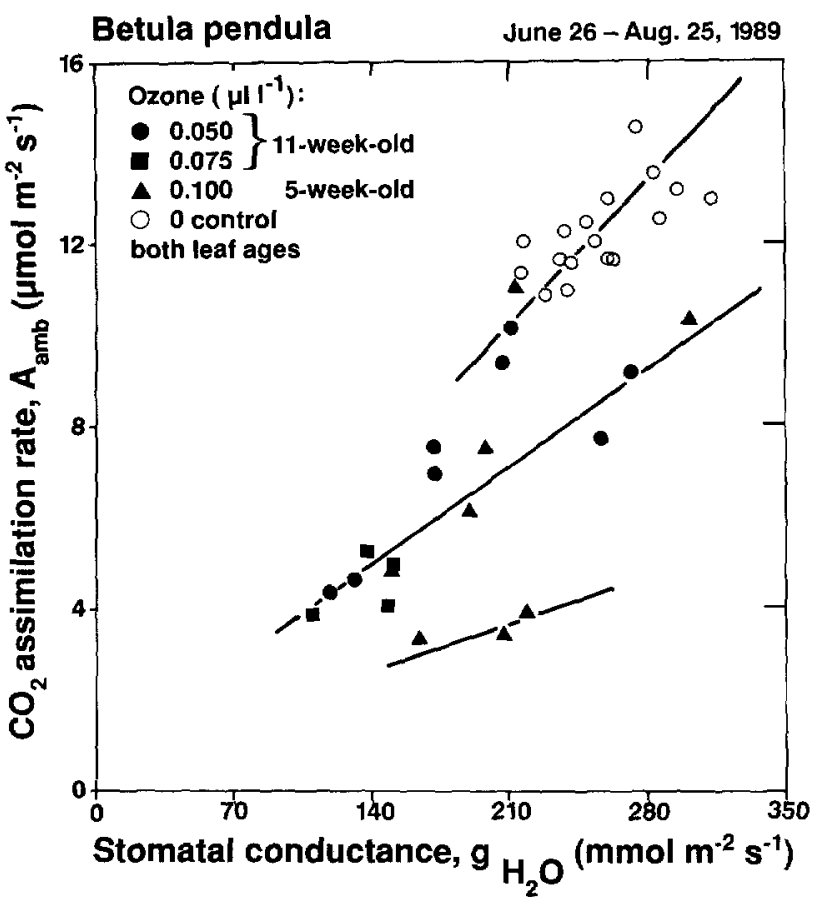

Fig. 4. Investigation I (the same leaves as in Fig. 2; each data point represents one individual leaf and plant) showing the relationship between the $\mathrm{CO}_{2}$ uptake rate $\left(\mathrm{A}_{\mathrm{amb}}\right)$ and stomatal conductance $\left(\mathrm{gH}_{2} \mathrm{O}\right)$ at $A_{a m b}$, of individual leaves at $c_{a}=340 \mu 1^{-1}$ (experiment 3 ). The upper line describes leaves with $E_{a m b} / A_{a m b}$ ratios of 225-298 mol mol-1 (no visual symptoms), the 2 nd line from top describes leaves of 300 $455 \mathrm{~mol} \mathrm{~mol}^{-1}$ (with early visual $\mathrm{O}_{3}$ symptoms up to established discoloration), and the lowermost line describes leaves of 626-734 mol mol-1 $^{-1}$ (all with established $\mathrm{O}_{3}$ discoloration)

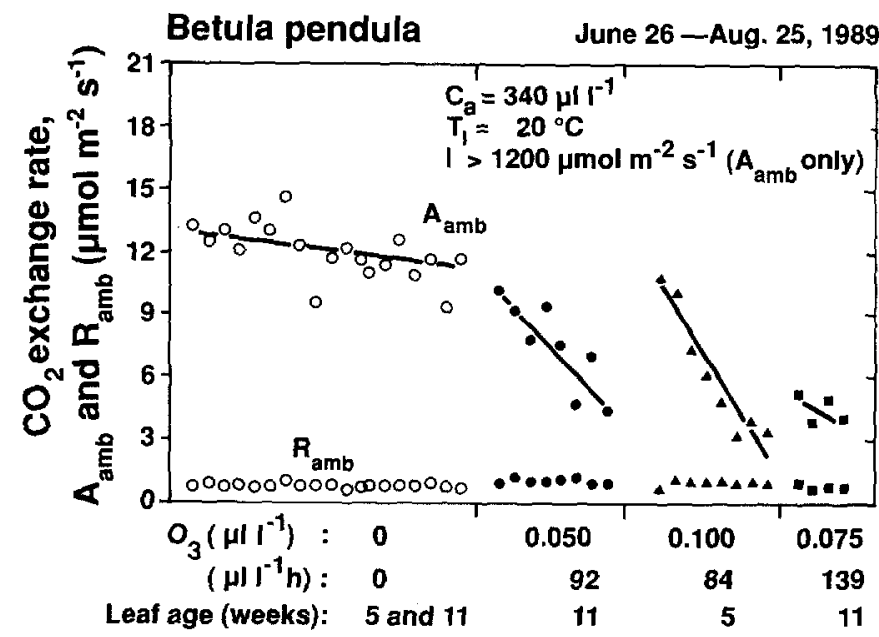

Fig. 5. Investigation I: pairs of $\mathrm{CO}_{2}$ uptake rate $\left(\mathrm{A}_{\mathrm{amb}}\right)$ and dark respiration rate $\left(R_{a m b}\right)$ at $c_{a}=340 \mu 1 l^{-1}$ of individual leaves and plants (experiment 4; the same leaves as in Fig. 2). Note that $R_{a m b}<0 \mu \mathrm{mol} \mathrm{m}^{-2} \mathrm{~s}^{-1}$ is projected into the scale of $A_{a m b}$; lines show tendency of change

spiration rate versus $\mathrm{CO}_{2}$ assimilation rate, $\mathrm{E}_{\mathrm{amb}} / \mathrm{A}_{\mathrm{amb}}$, at $c_{a}=340 \mu 11^{-1}$ (Fig. 2B). Thus, the 'water-use efficiency' (WUE) declined under the impact of ozone. Figure 4 shows that both $\mathrm{A}_{\mathrm{amb}}$ and $\mathrm{g}_{2} \mathrm{O}$ were reduced as $\mathrm{O}_{3}$ injury progressed. However, the decreasing slope in Fig. 4 reflects a stronger decline in $\mathrm{A}_{\mathrm{amb}}$ than in $\mathrm{g}_{2} \mathrm{O}$ and thus

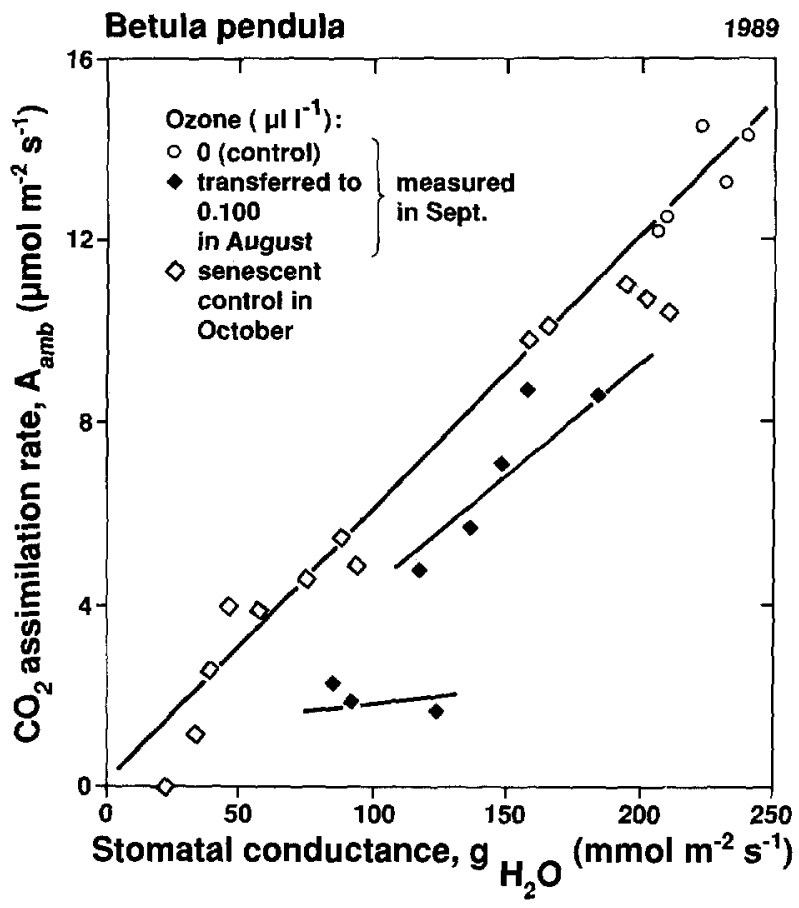

Fig. 6. Investigations II and III; showing the relationship between the $\mathrm{CO}_{2}$ uptake rate $\left(\mathrm{A}_{\mathrm{amb}}\right)$ and the stomatal conductance $\left(\mathrm{g}_{\mathrm{H}_{2} \mathrm{O}}\right)$ at $\mathrm{A}_{\mathrm{amb}}$, of individual leaves at $c_{a}=340 \mu^{1-1}$ (experiment 3; each data point represents one individual leaf and plant). All leaves had formed in mid-summer, leaves measured in September were 8 weeks old; the upper line describes leaves with $E_{a m b} / A_{\text {amb }}$ ratios of $180-241 \mathrm{~mol} \mathrm{~mol}^{-1}$ (control in September and during autumnal senescence in October), the 2 nd line from top describes leaves with ratios of $252-298 \mathrm{~mol} \mathrm{~mol}^{-1}$ (early visual $\mathrm{O}_{3}$ symptoms), and the lowermost line describes leaves with ratios of 463-897 $\mathrm{mol} \mathrm{mol}^{-1}$ (established $\mathrm{O}_{3}$ discoloration)

explains the decrease in WUE. In contrast to the $\mathrm{O}_{3}$-induced break-down in carbon gain, the dark respiration rate, $\mathrm{R}_{\mathrm{amb}}$ (at $\mathrm{c}_{\mathrm{a}}=340 \mu \mathrm{l}^{-1}$ ), did not differ between the treatments (Fig. 5).

The gas exchange of control leaves after $\mathrm{O}_{3}$ exposure (II) and during autumnal senescence (III)

The leaf gas exchange of control plants exposed to the $0.1 \mathrm{Ll}^{-1} \mathrm{O}_{3}$ treatment in mid-summer (II) responded similarly to ozone (Table 2B, Fig. $3 \mathrm{C}$, and decreasing WUE in Fig. 6) but more rapidly than in the leaves of (I). The changes in the $\mathrm{CO}_{2}$ uptake of ozonated leaves resembled that of senescent control leaves in autumn (III, Table 2B). However, the latter leaves not only maintained the stomatal sensitivity to $\mathrm{CO}_{2}$ (Fig. 3D) but also stable WUE until advanced yellowing (Fig. 6). Neither ozonation (II) nor senescence (III) caused $R_{a m b}$ to differ from that of midsummer control leaves (not shown). However, while both $\mathrm{A}_{\mathrm{amb}}$ and the nitrogen concentration, $\mathrm{N}$, declined in senescent leaves (Fig. 7), $\mathrm{N}$ tended to remain stable under ozonation. 


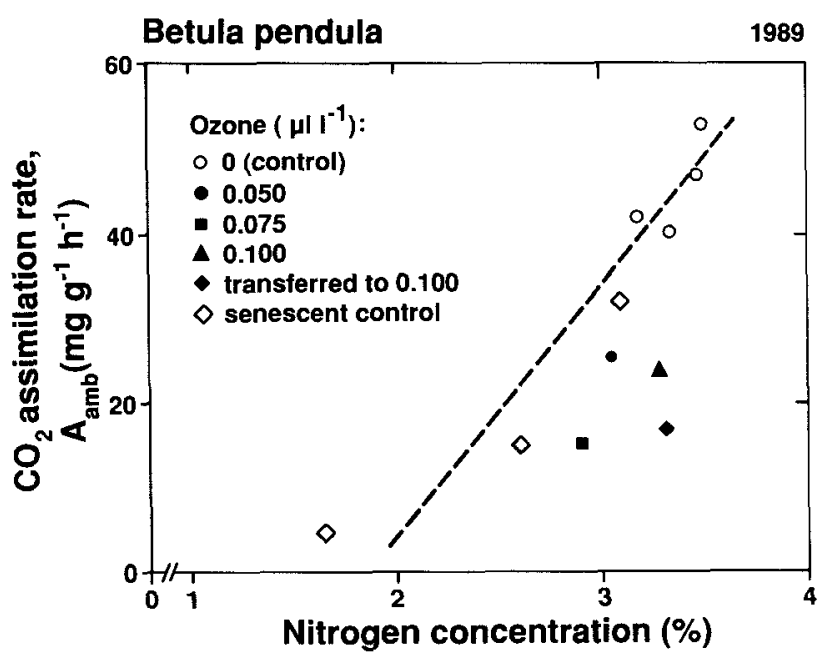

Fig. 7. $\mathrm{CO}_{2}$ uptake rate $\left(\mathrm{A}_{\mathrm{amb}}\right)$ as related to the nitrogen concentration $(\mathrm{N})$ of the experimental leaves. Mean $\mathrm{A}_{\mathrm{amb}}$ is assigned to $\mathrm{N}$ of pooled leaf samples per ozone treatment; the investigations I and II are depicted with their controls, investigation III gives three decline stages of the autumnal senescence; dashed line shows relation for control leaves

The structure of ozonated leaves and senescent control leaves $(I-I I I)$.

Increasing $\mathrm{O}_{3}$ concentration limited the leaf size but enhanced SLW and stomatal density (I, Table 3A), while stomatal apertures were narrowed by ozone before the occurrence of visual symptoms (Fig. 8A-D). Inside the ozonated leaves, unetchable droplet-like exudates abundantly formed on the walls of mesophyll cells (Fig. 8E). As the $\mathrm{O}_{3}$-induced discoloration set in, the mesophyll cells began to collapse (Fig. 8F; see intact control in Fig. 8G).
Control leaves exposed to ozone before completed extension growth (II) differed only in slightly reduced size and raised SLW from the control in $\mathrm{O}_{3}$-free air (Table 3B). Otherwise, stomatal narrowing and mesophyll degradation were similar to those in the ozonated leaves of (I). The $\mathrm{O}_{3}$-induced mesophyll collapse was also indicated by the increased inner leaf air space (Table 3 A, B). Senescent control leaves (III) displayed neither mesophyll collapse nor changes in the inner leaf air space (Table 3B).

\section{Discussion}

Before onsetting degradation, leaves formed under ozone (I) reached similar $A_{\max }$ as those in the control; however, their reduced size but enhanced SLW and stomatal density may indicate disturbed water relations during extension growth (Boyer 1970). The increased stomatal density was apparently overridden by the narrowing stomatal apertures already observed before discoloring, since $\mathrm{g}_{2} \mathrm{O}$ was not raised above the control. As stomatal closure progressed, stomatal sensitivity to $\mathrm{CO}_{2}$ was not lost, which underlines stomatal regulation as a rather robust mechanism of leaf function (cf. Field 1987). During the early leaf decline, guard cells and subsidiary cells appeared to be visually intact; this contrasts with findings from $\mathrm{SO}_{2}$ and $\mathrm{NO}_{\mathrm{x}}$ fumigations of collapsing subsidiary cells with widely opened pores in birch leaves (Wright 1988). Unless stomata are directly impaired by ozone, their closure might result from changed mesophyll metabolism (Winner et al. 1988), although the coupling between $\mathrm{A}_{\mathrm{amb}}$ and $\mathrm{gH}_{2} \mathrm{O}$ (Schulze and Hall 1982) was disturbed under $\mathrm{O}_{3}$ stress. The stomatal closure found did not limit the $\mathrm{CO}_{2}$ uptake as reflected in decreasing WUE and $\mathrm{CE}$ and increasing $\mathrm{c}_{i}$ (Reich 1983; Sasek and Richardson 1989; Krupa and Kickert 1989).

Table 3. Structural features per individual birch leaf (means of 5 leaves from different plants per ozone treatment \pm standard deviation. (See Materials and methods for leaf selection)

A: 8-week-old leaves in July formed under ozone fumigation (I)

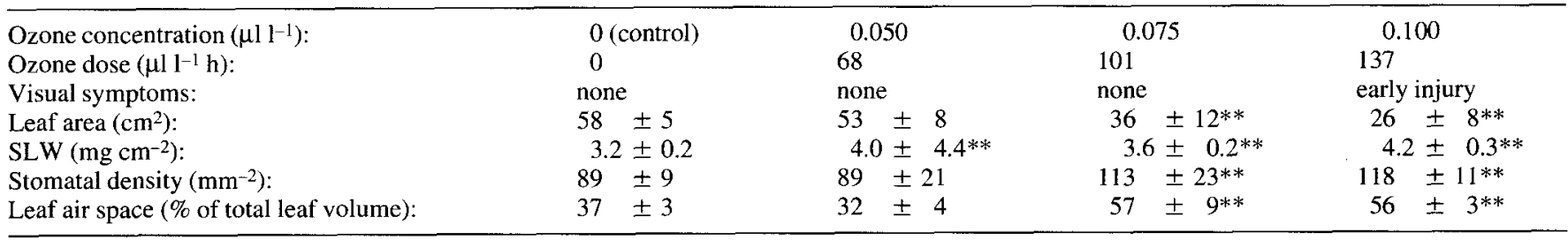

B: 8-week-old leaves of control plants transferred to the $0.1 \mu \mathrm{l}^{-1}$ ozone fumigation in August when leaves were 3 weeks old (II); senescent control leaves in autumn (III)

\begin{tabular}{|c|c|c|c|}
\hline & & (II) & (III) \\
\hline Ozone concentration $\left(\mu 11^{-1}\right)$ : & 0 (control) & 0.100 & 0 \\
\hline Ozone dose $\left(\mu 1 \mathrm{l}^{-1} \mathrm{~h}\right)$ : & 0 & 84 & 0 \\
\hline Visual symptoms: & none & early necrosis & yellowing \\
\hline Leaf area $\left(\mathrm{cm}^{2}\right)$ & $104 \pm 11$ & $85 \pm 12^{*}$ & $93 \pm 11$ \\
\hline $\operatorname{SLW}\left(\mathrm{mg} \mathrm{cm}^{-2}\right)$ & $4.7 \pm 0.2$ & $5.5 \pm 0.2 * *$ & $4.7 \pm 0.5$ \\
\hline Stomatal density $\left(\mathrm{mm}^{-2}\right)$ : & $69 \pm 8$ & $72 \pm 7$ & $67 \pm 8$ \\
\hline Leaf air space (\% of total leaf volume): & $34 \pm 1$ & $40 \pm 4^{* *}$ & $34 \pm 4$ \\
\hline
\end{tabular}

Fumigation treatments compared with controls by Student's $t$-test: $*$ significantly different at $5 \%$ and $* *$ at $1 \%$ 


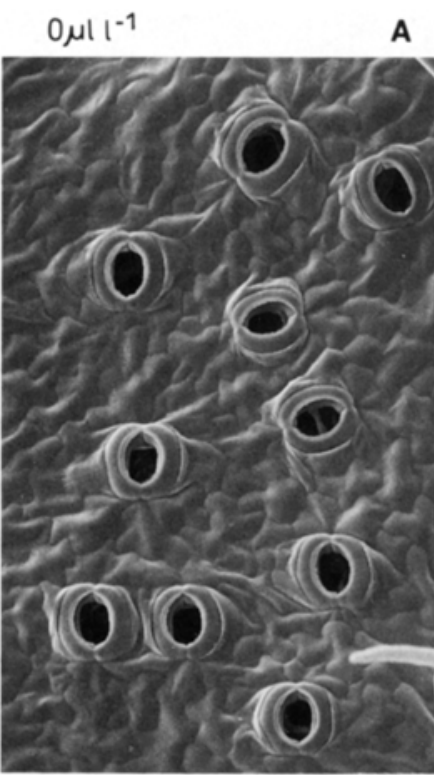

\section{$0.05 \mu l^{-1}$}

\section{B}

$0.075 \mu l^{-1}$

C

$0.10 \mu \mathrm{ll}^{-1}$

D
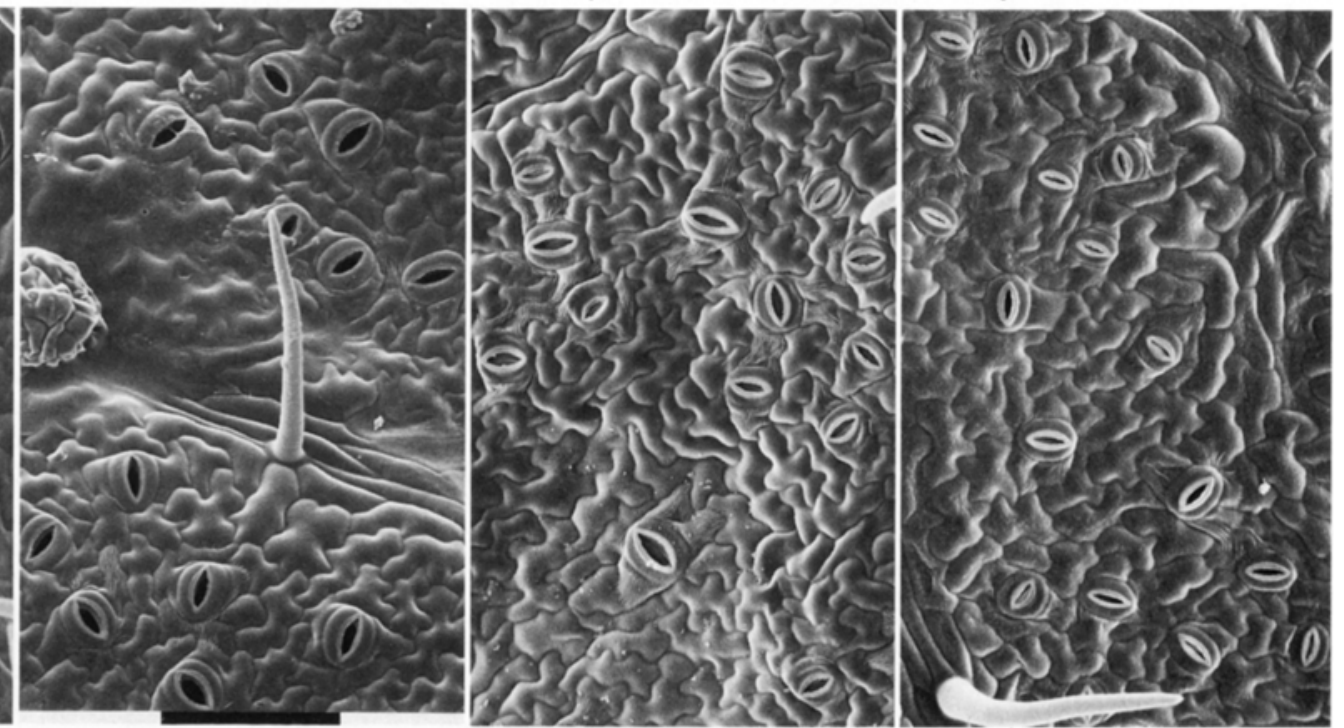

$0.1 \mathrm{~mm}$

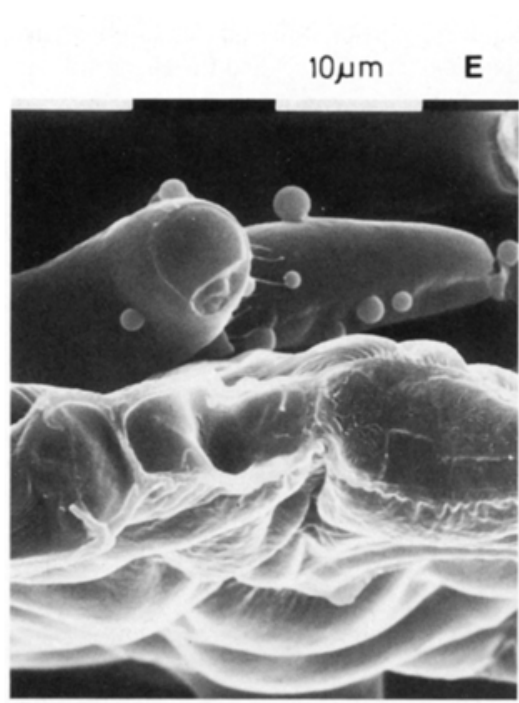

$0.10 \mu \mathrm{ll}^{-1}$

$0.1 \mathrm{~mm}$

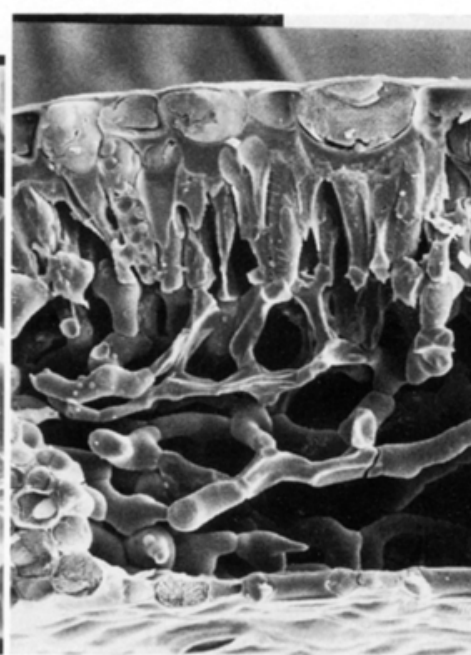

$0.05 \mu \mathrm{ll}^{-1}$

Fig. 8 A-G. Investigation I (low-temperature SEM). A-D: abaxial sides of birch leaves sampled at the same time and the same climatic conditions; gradual stomatal closure with increasing ozone concentration (scale in $\mathbf{A}, \mathbf{C}$, and $\mathbf{D}$ as shown in $\mathbf{B}$ ); $\mathbf{E}-\mathbf{G}$ : freeze-fractures through

Non-stomatal leaf changes reduced the carbon gain. $A_{\max }$ was more strongly lowered by ozone than QY (Reich 1983; Kuno 1980) and along with CE (Sasek and Richardson 1989). Such changes may be ascribed to impaired electron transport and to the amount and activity of the rubisco enzyme in the cells (Farquhar and Sharkey 1982). However, as the gas exchange was based on the entire area of one leaf side, $A_{\max }$ declined at least as the consequence of completely collapsed mesophyll cells, this structural break-down also biasing the apparent values of QY and $\mathrm{CE}$. Obviously, conclusions drawn from gas exchange about cell biochemistry might be misleading without taking into account changes in leaf structure. Nevertheless,

changes in the assimilatory metabolism of the remaining mesophyll cells cannot be excluded. The early and abundantly occurring exudates on the walls of mesophyll cells may indicate disturbances in the cell metabolism. While such exudates (Read 1990) might be a general stress indication, the $\mathrm{O}_{3}$ impact is assumed to mainly occur on the plasmalemma (Lange et al. 1989), thus very close to the cell wall. Therefore, changed light and dark reactions of photosynthesis (Urbach et al. 1989; Lehnherr et al. 1987) might be indirectly caused by responses of cell metabolism to that $\mathrm{O}_{3}$ impact.

The increasing inner air space evidently alleviated the gas diffusion inside ozonated leaves. Thus, according to 
Terashima et al. (1988), the decline found in CE represents the decreasing ' $\mathrm{CO}_{2}$ affinity' of entire ozonated leaves. Apparently, as degradation progressed, the mesophyll collapse gradually preceded the stomatal closure, thus decreasing WUE (Greitner and Winner 1989). The unchanged dark respiration rate under $\mathrm{O}_{3}$ stress seems to characterize fully developed leaves (Reich 1983; Hanson et al. 1988), but implies, at the given cell collapse, a raised respiration in the remaining mesophyll cells.

Compared with the leaves of (I), the more rapid but otherwise similar decay of control leaves ozonated in midsummer (II) may reflect seasonal changes in $\mathrm{O}_{3}$ sensitivity (Reich 1983) or result from the leaf growth mainly occurring in $\mathrm{O}_{3}$-free air. Senescent control leaves in autumn (III) resembled ozonated leaves in similarly declining $\mathrm{CO}_{2}$ uptake and maintained stomatal regulation (Field 1987). However, the autumnal discoloring of deciduous birch (bright yellowing) differed from that caused by $\mathrm{O}_{3}$ injury in that natural senescence requires metabolic and structural integrity (Thomas and Stoddart 1980) to assure the controlled leaf degradation as reflected in stable WUE and $c_{i}$ (Schulze and Hall 1982) and in nitrogen retranslocation (Medina 1984; Matyssek 1986; Adams et al. 1990). Probably, the break-down of ozonated birch leaves was too rapid to induce processes of natural senescence to the full extent. Therefore, $\mathrm{O}_{3}$-caused degradation of leaves should not be generally equated with senescence, as the congruence may be rather circumstantial. The mechanistic understanding of $\mathrm{O}_{3}$ injury and senescence must obviously be achieved by combined functional and structural analyses.

Acknowledgements. We gratefully acknowledge the technical assistance of Mr. U. Bühlmann, Mr. P. Bleuler, Mr. A. Burkart, Mr. P. Hatvani, and the support of Prof. H. Sticher (ETHZ) in nitrogen analysis. We thank Dr. R. Häsler, Dr. W. Landolt, Dr. R. Siegwolf and both reviewers for helpful suggestions on the manuscript and Mrs. M. J. Sieber for editing the English text.

\section{References}

Adams III WW, Winter K, Schreiber U, Schramel P (1990) Photosynthesis and chlorophyll fluorescence in relationship to changes in pigment and element composition of leaves of Platanus occidentalis $\mathrm{L}$. during autumnal senescence. Plant Physiol 93: 1164-1190

Beckett A, Read ND (1986) Low-temperature scanning electron microscopy. In: Aldrich HC, Todd WJ (eds) Ultrastructure techniques for microorganisms. Plenum, New York, pp 45-86

Boyer JS (1970) Leaf enlargement and metabolic rates in corn, soybean, and sunflower at various leaf water potentials. Plant Physiol 46: $233-235$

Brown KA, Roberts TM (1988) Effects of ozone on foliar leaching in Norway spruce [Picea abies (L.) Karst]: confounding factors due to $\mathrm{NO}_{\mathrm{x}}$ production during ozone generation. Environ Pollut 55: $55-73$

Farquzhar GD, Sharkey TD (1982) Stomatal conductance and photosynthesis. Annu Rev Plant Physiol 33: 317-345

Field CB (1987) Leaf-age effects on stomatal conductance. In: Zeiger E, Farquhar GD, Cowan IR (eds) Stomatal function. Stanford University Press, Stanford, pp 367-384

Greitner CS, Winner WE (1989) Effects of $\mathrm{O}_{3}$ on alder photosynthesis and symbiosis with Frankia. New Phytol 111: 647-656

Hanson PJ, McLaughlin SB, Edwards NT (1988) Net $\mathrm{CO}_{2}$ exchange of pinus taeda shoots exposed to variable ozone levels and rain chemistries in field and laboratory settings. Physiol Plant 74: 635 -642
Keller T (1976) Auswirkungen niedriger $\mathrm{SO}_{2}$-Konzentrationen auf junge Fichten. Schweiz Z Forstw 127: 237-251

Koch W, Lautenschlager K (1988) Photosynthesis and transpiration in the upper crown of a mature spruce in purified and ambient atmosphere in a natural stand. Trees 3: $213-222$

Koike T (1988) Leaf structure and photosynthetic performance as related to the forest succession of deciduous broad-leaved trees. Plant Species Biol 3: 77-87

Körner CH, Scheel JA, Bauer H (1979) Maximum leaf diffusive conduc tance in vascular plants. Photosynthetica 13: 45-82

Krupa SV, Kickert RN (1989) The greenhouse effect: impacts of ultraviolet-B (UV-B), radiation, carbon dioxide $\left(\mathrm{CO}_{2}\right)$, and ozone $\left(\mathrm{O}_{3}\right)$ on vegetation. Environ Pollut 61: 263-393

Kuno H (1980) Effects of photochemical oxidants on the growth of poplar cuttings. II Effects of photochemical oxidant on chlorophyll contents, photosynthetic and dark respiratory rates, soluble carbohydrate and nitrogen contents in leaves of different ages. Taiki Osen Gakkaishi 15: 155-162

Lange OL, Beyschlag W, Tenhunen JD (1987) Control of leaf carbon assimilation - input of chemical energy into ecosystems. In: Schulze E-D, Zwölfer H (eds) (Ecological studies vol 61) Springer, Berlin Heidelberg New York, pp 149-163

Lange OL, Heber U, Schulze E-D, Ziegler H (1989) 3-D Atmospheric pollutants and plant metabolism. In: Schulze E-D, Lange OL, Oren R (eds) Forest decline and air pollution. (Ecological studies, vol 77) Springer, Berlin Heidelberg New York, pp 238-273

Lehnherr B, Grandjean A, Mächler F, Fuhrer J (1987) The effect of ozone in ambient air on ribulosebisphosphate carboxylase/oxygenase activity decreases photosynthesis and grain yield in wheat. J Plant Physiol 130: 189-200

Matyssek R (1986) Carbon, water and nitrogen relations in evergreen and deciduous conifers. Tree Physiol 2: 177- 187

Medina E (1984) Nutrient balance and physiological processes at the leaf level. In: Medina E, Mooney HA, Vazquez-Yanes C (eds) Physiological ecology of plants of the wet tropics. Junk, The Hague, pp 139 154

Mohren GMC (1988) Report on group discussions and final recommendations. In: Bervaes J, Mathy P, Evers P (eds) Relationships between above and below ground influences of air pollutants on forest trees. COST-612 Air Pollut Res Rep 16: 263-270

Mooney HA, Winner WE (1988) Carbon gain, allocation, and growth as affected by atmospheric pollutants. In: Schulte-Hostede $S$, Darral NM, Blank LW, Wellburn AR (eds) Air pollution and plant metabolism. Elsevier, London, pp 272-287

Müller T, Guggenheim R, Düggelin M, Scheidegger C (1991) Freezefracturing for conventional and field emission low-temperature scanning electron microscopy: the scanning cryo unit SCU 020. J Microse (Oxford) 161 (in press)

Read ND (1990) Low-temperature scanning electron microscopy of fungi and fungus-plant interactions. In: Mendgen $\mathrm{K}$, Lesemann DE (eds) Electron microscopy applied in plant pathology. Springer, Berlin Heidelberg New York (in press)

Reich PB, Amundson RG (1985) Ambient levels of ozone reduce net photosynthesis in tree and crop species. Science 230: 566-570

Reich PB (1983) Effects of low concentrations of $\mathrm{O}_{3}$ on net photosynthesis, dark respiration, and chlorophyll contents in aging hybrid poplar leaves. Plant Physiol 73: 291-296

Reich PB (1987) Quantifying plant response to ozone: a unifying theory. Tree Physiol 3: 63-91

Sasek TW, Richardson CJ (1989) Effects of chronic doses of ozone on loblolly pine: photosynthetic characteristics in the third growing season. For Sci 35: $745-755$

Scheidegger C, Günthardt-Goerg MS, Matyssek R, Hatvani P (1991) Low temperature SEM of birch leaves after exposure to ozone. J Microsc (Oxford) 161 (in press)

Schulze E-D (1989) Air pollution and forest decline in a spruce (Picea abies) forest. Science 244: 776-783

Schulze E-D, Hall AE (1982) Stomatal responses, water loss, and nutrient relations in contrasting environments. In: Lange OL, Nobel PS, Osmond CB, Ziegler H (eds) Encyclopedia of plant ecology 
(vol 12 B) physiological plant ecology II. Springer, Berlin Heidelberg New York, pp 182-230

Terashima I, Wong S-C, Osmond CB, Farquhar GD (1988) Characterisation of non-uniform photosynthesis induced by abscisic acid in leaves having different mesophyll anatomies. Plant Cell Physiol 29: $385-$ 394

Thomas HT, Stoddart JT (1980) Leaf senescence. Annu Rev Plant Physiol 31: $83-111$

Urbach W, Schmidt W, Kolbowski J, Rümmele S, Reisberg E, Steigner W, Schreiber U (1989) Wirkungen von Umweltschadstoffen auf Photosynthese und Zellmembranen von Pflanzen. In: Reuther M,
Kirchner M (eds) 1. Statusseminar der PBWU zum Forschungsschwerpunkt Waldschäden. GSF München, pp 195-206

Winner WE, Gillespie C, Shen W-S, Mooney HA (1988) Stomatal responses to $\mathrm{SO}_{2}$ and $\mathrm{O}_{3}$. In: Schulte-Hostede $\mathrm{S}$, Darral NM, Blank LW, Wellburn AR (eds) Air pollution and plant metabolism. Elsevier, London, pp 255-271

Wright EA (1988) Some effects of low levels of sulphur dioxide and nitrogen dioxide on the control of water loss by Betula spp. In: Mathy P (ed) Air pollution and ecosystems. Reidel, Dordrecht, pp 760-765 